DOI: $10.217672573-5365.100028$

\title{
Bacterial Uropathogens in Urinary Tract Infection and Antibiotic Susceptibility Pattern in Riyadh Hospital, Saudi Arabia
}

\author{
Samiah HS Al-Mijalli
}

Biology Department, Princess Norah Bent Abdul Rahman University, Scientific Section, Riyadh, Saudi Arabia

Corresponding author: Samiah HS Al-Mijalli, Biology Department, Princess Norah Bent Abdul Rahman University, Scientific Section, Riyadh, Saudi Arabia, Tel: 966118220000; E-mail: dr.samiah10@hotmail.com

Rec date: Apr 12, 2017; Acc date: Apr 27, 2017; Pub date: Apr 29, 2017

Citation: Al-Mijalli SHS. Bacterial Uropathogens in Urinary Tract Infection and Antibiotic Susceptibility Pattern in Riyadh Hospital, Saudi Arabia. Cell Mol Med 2017, 3:1.

\section{Abstract}

Background: Urinary tract infection (UTI) is one of the commonest infections encountered by clinicians and despite the widespread availability of antimicrobial agents. UTI has become difficult to treat because of appearance of pathogens with increasing resistance to antimicrobial agents.

The aim and objectives of this study were to determine the etiological Bacterial pathogens of the UTI and to determine the antibiotic sensitivity pattern of pathogens isolated.

Results: The present study was carried out from the Central Laboratory of Riyadh Hospital in Saudi Arabia from January 2015 to Jun 2015.Total 116 urine samples were tested bacteriologically and for antibiotic susceptibility using standard procedures.

This study describes the relationships between sex, isolated bacterial agents and antibiotic resistance of UTIs. Out of 116 samples of out patients, urinary tract infection (UTI), of these $70(60.35 \%)$ belonged to female and $46(39.66 \%)$ samples belonged to male patients, while adult patients included (22.41\%) of female as well as male patients with the same percentage. It was found that old adult women have a higher prevalence of UTI than men. Escherichia coli was the most common isolate (78.45\%) followed by Klebsiella pneumoniae ( $21.56 \%$ ) amongst the gram-negative bacilli. Also, the results showed that, E. coli occurred more frequently in women $(50 \%)$ than in men (28.45\%).

All isolates of $E$. coli and $K$. pneumoniae were high susceptible to Meropenem, Imipenem, Colistin, Ertapenem and Amikacin.

Conclusions: This study showed that $E$. coli isolates were the predominant pathogens and showed increasing resistance pattern to the commonly prescribed drugs in private practice that in turn leaves the clinicians with very few alternative options of drugs for the treatment of UTIs.

Keywords: Urinary tract; Infections; Antibiotic susceptibility; Outpatients

\section{Abbreviations}

UTI: Urinary Tract Infection; Escherichia coli: E. coli; Klebsiella pneumoniae: K. pneumoniae; CLSI: Clinical and Laboratory Standards Institute

\section{Introduction}

Urinary tract infections (UTI) are one of the most common infectious diseases diagnosed in outpatients as well as in hospitalized patients, and can lead to significant mortality [1]. UTI account for a large proportion of antibacterial drug consumption and have large socio-economic impacts [2]. UTIs refer to the presence of microbial pathogens within the urinary tract and it is usually classified by the infection site:bladder (cystitis), kidney (pyelonephritis), or urine (bacteriuria) and also can be asymptomatic or symptomatic, UTIs that occur in a normal genitourinary tract with no prior instrumentation are considered as "uncomplicated," whereas "complicated" infections are diagnosed in genitourinary tracts that have structural or functional abnormalities, including instrumentation such as indwelling urethral catheters, and are frequently asymptomatic $[3,4]$. Urinary tract infection (UTI) is one of the most common infections affecting different age group of the patients [5]. The international studies have shown that UTIs in women are very common; therefore, one in five adult women experience UTI in her life and it is extremely common, clinically apparent, worldwide patient problem [6-9]. More than $95 \%$ of urinary tract infections are caused by a single bacterial species. E. coli is the most frequent infecting organism in acute infection [10,11]. Klebsiella, Staphylococci, Enterobacter, Proteus, Pseudomonas, and Enterococci species are more often isolated from inpatients, whereas there is a greater preponderance of $E$. coli in an outpatient population [12]. The relative frequency of the pathogens varies depending upon age, sex, catheterization, and hospitalization [13]. The 
most frequent uropathogens were Gram negatives which made up $80.9 \%$ of all the isolates. E. coli was the most common bacteria isolated from urine samples in both outpatients and inpatients of both sexes [14].

Treatment of UTI is often started empirically and therapy is based on information determined from the antimicrobial resistance pattern of the urinary pathogens [15]. The prevalence of antimicrobial resistance among urinary pathogens has been increasing worldwide due to aberrant use of antibiotics in practice [16,17]. Distribution of urinary pathogens and their susceptibility to antibiotics varies regionally so it becomes necessary to have knowledge of distribution of these pathogens and their susceptibility to antibiotics in a particular setting $[18,19]$. The estimation of local etiology and susceptibility profile could support the most effective empirical treatment [20].

The aim of this study was to determine bacterial etiologic agents responsible for urinary tract infection and to evaluate their in vitro susceptibility pattern to commonly used antimicrobial agents. This study is important to facilitate the effective treatment and management of patient with symptoms of urinary tract infection referred to the Central Laboratory of Riyadh Hospital, Saudi Arabia on a period of (January 2015-Jun 2015).

\section{Materials and Methods}

A prospective study was planned to determine the etiological Bacterial pathogens of the UTI and to determine the antibiotic sensitivity pattern of pathogens isolated. Total 116 samples of urinary tract infection (UTI) outpatients, were collected during this study period. For collection of urine samples patients were advised to collect a clean catch midstream urine specimen in a sterile, wide mouthed leak proof container supplied by the Central Riyadh Hospital and bring to the laboratory as early as possible.

There were $70(60.35 \%)$ urine samples from female patients and 46 (39.66\%) from male patients. Adult patients were sampled by clean catch midstream urine, and children aged less than 3 years were sampled using sterile urine bags.

In this survey, cases with or without clinical symptoms of UTIs were studied retrospectively [7,21]. Data collection were conducted by a questionnaire consisting of short-answer questions including, Dates, Bacterial agents (First, Second and Third Pathogen), Diagnostic techniques, Sex and Age of patients, Predisposing factors and Mortality. In the present study, the patients who referred to the Central Riyadh Hospital were studied, on a period of (January 2015-Jun 2015).

\section{Isolation and Identification Bacterial Pathogens}

Total 116 urine samples were collected during this study period. A measured amount of urine, using calibrated loop method was inoculated to nutrient agar medium (Merck, Germany) for colony count. Equal or more than $104 \mathrm{CFU} / \mathrm{ml}$ of a single potential pathogen or for each of two potential pathogens interpreted as positive UTI and a result of 102 $\mathrm{CFU} / \mathrm{ml}$ to $104 \mathrm{CFU} / \mathrm{ml}$ was repeated. A less than $102 \mathrm{CFU} / \mathrm{ml}$ was interpreted as negative UTI [22]. Urine specimens were cultured for isolation of the microbial agents of UTI on blood agar and MacConky Agar media. The plates were then incubated at $37^{\circ} \mathrm{C}$ aerobically for $24 \mathrm{hrs}$. They were then examined for bacterial growth. All the bacteria isolated from urine in this study were identified using conventional biochemical tests [23-25]. More than 95\% of urinary tract infections are caused by a single bacterial colony count of bacteria in UTI.

Table 1 Frequency of bacterial agents isolated from urine specimens and their relation to sex and age group in this study.

\begin{tabular}{|c|c|c|c|c|c|c|}
\hline \multirow{2}{*}{$\begin{array}{l}\text { Type } \\
\text { Sex }\end{array}$} & \multicolumn{2}{|c|}{ Children* } & \multicolumn{2}{|c|}{ Young** } & \multicolumn{2}{|c|}{ Adult*** } \\
\hline & $\mathrm{F}$ & $M$ & $\mathrm{~F}$ & $M$ & $\mathrm{~F}$ & $M$ \\
\hline Total count & 20 & 12 & 24 & 8 & 26 & 26 \\
\hline $\begin{array}{l}\text { Of patients } \\
\%\end{array}$ & 17.42 & $\begin{array}{l}10 . \\
35\end{array}$ & 20.69 & $\begin{array}{l}6.9 \\
0\end{array}$ & 22.41 & $\begin{array}{l}22.4 \\
1\end{array}$ \\
\hline \multicolumn{7}{|c|}{ Bacterial spp. } \\
\hline Escherichia & 16 & 9 & 18 & 5 & 24 & 19 \\
\hline $\begin{array}{l}\text { coli } \\
\%\end{array}$ & 13.79 & $\begin{array}{l}7.7 \\
6\end{array}$ & 15.52 & $\begin{array}{l}4.3 \\
1\end{array}$ & 20.69 & $\begin{array}{l}16.3 \\
8\end{array}$ \\
\hline $\begin{array}{l}\text { Klebsiella } \\
\text { pneumonia } \\
\%\end{array}$ & $\begin{array}{l}4 \\
3.45\end{array}$ & $\begin{array}{l}3 \\
2.5 \\
9\end{array}$ & $\begin{array}{l}6 \\
5.17\end{array}$ & $\begin{array}{l}3 \\
2.5 \\
9\end{array}$ & $\begin{array}{l}2 \\
1.72\end{array}$ & $\begin{array}{l}7 \\
6.03\end{array}$ \\
\hline
\end{tabular}

Total number of out patients $=116{ }^{*}$ Children $(0-14$ years $) * *$ Young $(15-50$ years) ${ }^{\star \star *}$ Adult (51-100 years)

\section{Antibiotic Susceptibility Testing}

In the present study antimicrobial susceptibility testing was done on Mueller- Hinton agar using disk diffusion (Kirby Bauer's) method according to the clinical and laboratory standards institute (CLSI) guidelines using the following 21 antimicrobial agents: Amikacin $(30 \mu \mathrm{g})$, Gentamicin $(10 \mu \mathrm{g})$, Ciprofloxacin $(5 \mu \mathrm{g})$, Ertapenem $(30 \mu \mathrm{g})$, Nitrofurantoin (300 $\mu \mathrm{g})$, Imipenem (30 $\mathrm{gg})$, Meropenem (30 $\mu \mathrm{g})$, Trimethoprim/ Sulfamethoxazole $(25 \mu \mathrm{g})$ [15], Tigecycline $(30 \mu \mathrm{g})$, Piperacillin/ Tazobactam (30 $\mu \mathrm{g})$, Levofloxaacin $(30 \mu \mathrm{g})$, Colistin, Cephalothin, Cefuroxime $(10 \mu \mathrm{g})$, Ceftriaxone $(30 \mu \mathrm{g})$, Ceftazidime $(30 \mu \mathrm{g})$, Cefoxitin $(30 \mu \mathrm{g})$, Cefepime (30 $\mu \mathrm{g})$, Aztreonam $(30 \mu \mathrm{g})$, Ampicillin $(10 \mu \mathrm{g})$ and Amoxicillin $(30 \mu \mathrm{g})$ for all Bacterial isolates.

Data were entered and analyzed using SPSS version 12.0.1 windows. Discrete variables were expressed as percentages and proportions were compared using the Chi-square test. Statistical significance difference was considered at value of $\mathrm{p}<0.05$ (IBM, Chicago, IL, USA).

\section{Results}

Total 116 samples of urinary tract infection (UTI) outpatients, were collected during this study period. Among 
these $70(60.35 \%)$ belonged to female and $46(39.66 \%)$ samples belonged to male patients. Among them adult patients occurred in $(22.41 \%)$ of female as well as male patients with the same percentage, and most of them were old adults (Table 1). The most common isolates in this study have been the Gram-negative bacilli which accounts for $100 \%$ of the total positive isolates. In the Gram-negative bacilli, the predominant isolate was the Escherichia coli (78.45\%) followed by Klebsiella pneumoniae $(21.56 \%)$, which is the second most prevalent pathogen of UTI. Beside them, it was found that four types of other bacterial species have been isolated from three cases who infected with $E$. coli or $K$. pneumoniae and they were (Pseudomonas aeruginosa (2.58\%), Morganella morganai (0.86\%), Proteus mirabilis $(0.86 \%)$ and a Gram-positive Enterococcus faecalis $(0.86 \%)$, Table 2 shows the detailed frequency of all the isolates identified. The most common pathogens isolated were $E$. coli $(78.45 \%)$, from female patients (50\%) and (28.45\%) from male patients. The high percentage of $K$. pneumoniae $(6.03 \%)$, was isolated from adult male patients (Table 2).

Table 2 Distribution of positive bacterial isolates identified from urine samples and their relation to sex in this study.

\begin{tabular}{|c|c|c|c|c|c|c|}
\hline Bacterial spp. & E. coli & K. pneumonia & $P$. aeruginosa & M. morganii & E. faecalis & P. mierabilis \\
\hline Females & $\begin{array}{l}58 \\
(50 \%)\end{array}$ & $\begin{array}{l}12 \\
(10.35 \%)\end{array}$ & $\begin{array}{l}2 \\
(1.72 \%)\end{array}$ & $\begin{array}{l}1 \\
(0.86 \%)\end{array}$ & --- & --- \\
\hline Males & $\begin{array}{l}33 \\
(28.45 \%)\end{array}$ & $\begin{array}{l}13 \\
(11.21 \%)\end{array}$ & $\begin{array}{l}1 \\
(0.86 \%)\end{array}$ & --- & $\begin{array}{l}1 \\
(0.86 \%)\end{array}$ & $\begin{array}{l}1 \\
(0.86 \%)\end{array}$ \\
\hline Total count & $91(78.45 \%)$ & $\begin{array}{l}25 \\
(21.56 \%\end{array}$ & $\begin{array}{l}3 \\
(2.58 \%)\end{array}$ & $\begin{array}{l}1 \\
(0.86 \%)\end{array}$ & $\begin{array}{l}1 \\
(0.86 \%)\end{array}$ & $\begin{array}{l}1 \\
(0.86 \%)\end{array}$ \\
\hline
\end{tabular}

\section{Bacterial Susceptibility}

The comparison of the susceptibility pattern of organisms to various antimicrobial agents from all the specimens was shown in Table 3. E. coli showed high susceptibility $(98.90 \%)$ to each of amikacin, meropenem, imipenem, ertapenem and colistin. But, to tigecycline $(93.41 \%)$, to nitrofurantion $(89.01 \%)$, to cefoxitin (86.81\%) and to piperacillin/tazobactam $(84.62 \%)$. Nevertheless, there was a decreased susceptibility to gentamicin (64.84\%). E. coli exhibited resistance to the commonly used antibiotics as shown in Table 3.

Also, K. pneumoniae was highly susceptible to Meropenem (96\%), Imipenem (96\%), Colistin (92\%), Ertapenem (88\%), Amikacin and Levofloxacin (80\%), but there was a low susceptibility pattern of $K$. pneumoniae to cefoxitin (76\%), to Piperacillin/Tazobactam (56\%) and to Ciprofloxacin (48\%), to Gentamicin (28\%), to Tigecycline (20\%), to Nitrofurantion (16\%). The organism showed high resistance to common used urinary antibiotics as in E. coli except Levofloxacin (Table 3). E. coli and $K$. pneumoniae showed the highest percentage of resistance to Ampicillin, Aztreonam, Cefepime, Ceftriaxone, Cefuroxime, Cephalothin, Ceftazidime and Amoxicillin (Table 3).

\section{Discussion}

This study describes the relationships between sex, isolated bacterial agents and antibiotic resistance of UTIs. Among 116 samples of outpatient's urinary tract infection (UTI), of these 70 (60.35\%) belonged to female and 46 (39.66\%) samples belonged to male patients, while adult patients included (22.41\%) of female as well as male patients with the same percentage.

Table 3 Distribution of antibiotic susceptibility amongst the bacterial isolates from urine specimens.

\begin{tabular}{|l|l|l|}
\hline Antibiotic susceptibility (\%) & K. pneumonia & E. coli \\
\hline \multirow{2}{*}{ Ciprofloxacin } & $28 \% \mathrm{R}$ & $62.64 \% \mathrm{R}$ \\
\hline & $48 \% \mathrm{~S}$ & $25.56 \% \mathrm{~S}$ \\
\hline Trim/Sulfam & $76 \% \mathrm{R}$ & $70.33 \% \mathrm{R}$ \\
\hline Tigecycline & $20 \% \mathrm{~S}$ & $93.41 \% \mathrm{~S}$ \\
\hline Piperacillin/Ta & $56 \% \mathrm{~S}$ & $84.62 \% \mathrm{~S}$ \\
\hline Nitrofurantion & $16 \% \mathrm{~S}$ & $89.01 \% \mathrm{~S}$ \\
\hline Meropenem & $96 \% \mathrm{~S}$ & $98.90 \% \mathrm{~S}$ \\
\hline Levofloxacin & $80 \% \mathrm{~S}$ & $63.23 \% \mathrm{R}$ \\
\hline Imipenem & $96 \% \mathrm{~S}$ & $98.90 \% \mathrm{~S}$ \\
\hline Gentamicin & $28 \% \mathrm{~S}$ & $64.84 \% \mathrm{~S}$ \\
\hline Ertapenem & $88 \% \mathrm{~S}$ & $98.90 \% \mathrm{~S}$ \\
\hline Colistin & $92 \% \mathrm{~S}$ & $98.90 \% \mathrm{~S}$ \\
\hline Cephalothin & $88 . \% \mathrm{R}$ & $98.89 \% \mathrm{R}$ \\
\hline Cefuroxime & $88 \% \mathrm{R}$ & $98.89 \% \mathrm{R}$ \\
\hline Ceftriaxone & $88 \% \mathrm{R}$ & $98.89 \% \mathrm{R}$ \\
\hline Ceftazidime & $84 \% \mathrm{R}$ & $98.90 \% \mathrm{R}$ \\
\hline Cefoxitin & $76 \% \mathrm{~S}$ & $86.81 \% \mathrm{~S}$ \\
\hline Cefepime & $88 \% \mathrm{R}$ & $96.70 \% \mathrm{R}$ \\
\hline Aztreonam & $88 \% \mathrm{R}$ & $98.90 \% \mathrm{R}$ \\
\hline Ampicillin & $88 \% \mathrm{R}$ & $98.90 \% \mathrm{R}$ \\
\hline Amoxicillin & $84 \% \mathrm{R}$ & $98.90 \% \mathrm{R}$ \\
\hline Amilkacin & $98.90 \% \mathrm{~S}$ \\
\hline & & \\
\hline & 80 & \\
\hline
\end{tabular}

Similar study, was conducted in Rawalpindi by Inam Ullah Khan et al. revealed that the bulk of the urinary isolates were 
from female patients (70\%) as UTIs are frequent in females due to short urethra. The international studies have shown that UTIs in women are very common; therefore, one in five adult women experience UTI in her life and it is extremely common, clinically apparent, worldwide patient problem $[7,8,9,13,26,27]$. Approximately 1 in 3 women will require antimicrobial treatment for a UTI before age 24 , and $40 \%$ to $50 \%$ of women will have a UTI during their lifetime [28]. The sex distribution of patients in our study is consistent with those of other reported studies, showing a statistically predominance of females with UTI $[29,30]$.

This result is similar to those reported from many other centers [31,32]. It has been extensively reported that adult women have a higher prevalence of UTI than men, principally owing to anatomic and physical factors [33]. The elevated incidence of infection among females is related to differences between the male and female genitourinary systems in anatomy and microflora [34]. The Enterobacteriaceae family were the most common microorganism isolated of Urinary tract infection in the present study accounting $100 \%$ of total isolated bacteria. Amongst them E. coli (78.45\%) was the most predominant bacteria, followed by $K$. pneumoniae (21.56 \%), which is the second most prevalent pathogen of UTI, and this finding is in agreement with others finding too [2,20,22,35-37]. Several authors around the world have been reported that the Gram-negative bacteria of $E$. coli and Klebsiella spp. being the most frequent organisms causing UTIs $[3,6,7,38,39]$. Also, $E$. coli is the major aetiological agent in causing UTI, which accounts for up to $90 \%$ of cases [11]. While, In the present study $E$. coli occurred more frequently in women (50\%) than in men $(28.45 \%)$, also these findings consisting with the results of Ziad Daoud and Claude Afif [29].

$E$. coli and $K$. pneumoniae showed the highest percentage of resistance to Ampicillin, Aztreonam, Cefepime, Ceftriaxone, Cefuroxime, Cephalothin, Ceftazidime and Amoxicillin. On the other hand, very low resistance was detected to antibiotics such as Ciprofloxacin and Trimethoprim/Sulfamethoxazole for all these isolates. However, Manikandan and Amsath found that, Klebsiella spp. isolates showed higher resistance were Amoxiclillin (88.9\%), Ampicillin (83.3\%), Cotrimoxazole (70.8\%) nalidixic acid (50.6\%), nitrofurantoin (50.0\%) and Norfloxacin (25.0\%). In the present study, all UTI isolates of $E$. coli and $K$. pneumoniae were high susceptible to Meropenem, Imipenem, Colistin, Ertapenem and Amikacin. This study is comparable with the results reported by Astal et al. [40] and Mclsaac et al. [41]. Based on the results of the present study, it was revealed that the susceptibility of bacteria to Ciprofloxacin and other antibiotics was similar to many studies $[40,42]$. But, there was a low susceptibility pattern of $K$. pneumoniae to nitrofurantion. It was found that fluoroquinolones should only be used for the treatment of acute UTIs for women who should not be prescribed nitrofurantoin, trimethoprimsulfamethoxazole or Fosfomycin [43].

\section{Conclusion}

It is concluded that, females have a higher prevalence of UTI than males. As especially old adult women were more affected by UTI than men. Gram-negative bacilli (Enterobacteracea) were responsible for urinary tract infections and $E$. coli occurred more frequently in women than in men.

Most of the strains were multi-drugs resistant. The most common isolated bacteria from urinary tract Infections was $E$. coli and the most effective antimicrobial agents were Amikacin, Meropenem, Imipenem, Colistin and Ertapenem against $E$. coli and $K$. pneumoniae. In order to prevent or decrease resistance to antibiotics, the use of antibiotics should be kept under supervision, should be given in appropriate doses for an appropriate period of time $[3,44]$.

\section{Ethics Approval and Consent to Participate}

1. A consent to collect the samples is obtained from different hospitals and centers included in the study.

2. Valid consent of the person under the study $[45,46]$

3. Maintaining confidentiality of information obtained from subjects under the study.

4. Complete information regarding risk factors is handed to all patients under the study and no concealment what so over.

5. Results of samples collected are donated to all patients included in the study and some sample results were dispatched to physicians for treatment prescription [47-49].

\section{Consent for Publication}

Not applicable.

\section{Availability of Data and Materials}

Please contact author for data requests.

\section{Conflict of Interest}

The author declares that she has no conflict of interest.

\section{Funding}

I thank the University of Princess Nourah bint Abdul Rahman to support me.

\section{References}

1. Schaeffer AJ (2002) Infections of the urinary tract. Campbell's urology 1: 515-602.

2. Dias Neto JA. Dias Magalhães da Silva L, Carlos Pereira Martins A, Brianezi Tiraboschi R, Alonso Domingos AL, et al. (2003) Prevalence and bacterial susceptibility of hospital acquired urinary tract infection. Acta Cir Bras 18: 36-38.

3. Nerurkar A, Solanky P, Naik SS (2012) Bacterial pathogens in urinary tract infection and antibiotic susceptibility pattern. J Pharm Biomed Sci 21(12). 
4. Stamm WE, Hooton TM (1993) Management of urinary tract infections in adults. N Engl J Med 329: 1328-1334.

5. Yusuf MA, Begum A, Ahsan CR (2015) Antibiotic sensitivity pattern of gram negative uropathogenic bacilli at a private hospital in Dhaka city. Al Ameen J Med Sci 1: 189-194.

6. Behzadi P, Behzadi E, Yazdanbod H, Aghapour R, Cheshmeh MA, et al. (2010) A survey on urinary tract infections associated with the three most common uropathogenic bacteria. Maedica 5: 111.

7. Behzadi P, Behzadi E (2008) The microbial agents of urinary tract infections at central laboratory of Dr. Shariati Hospital, Tehran, IRAN. Turk Klin Tip Bilim 28: 445-449.

8. Hummers-Pradier E, Ohse AM, Koch $M$, Heizmann WR, Kochen MM (2005) Management of urinary tract infections in female general practice patients. J Fam prac 22: 71-77.

9. Howes DS (2010) Urinary Tract Infection, Female. J eMed.

10. Jellheden B, Norrby RS, Sandberg T (1996) Symptomatic urinary tract infection in women in primary health care: Bacteriological, clinical and diagnostic aspects in relation to host response to infection. Scand J Prim Health Care 14: 122-128.

11. Moges F, Genetu A (2002) Antibiotic sensitivity of common bacterial pathogens in urinary tract infections at Gonder Hospital, Ethiopia. East Afr Med J 79: 140-142.

12. Bronsema DA, Adams JR, Pallares R (1993) Secular trends in rates and etiology of nosocomial urinary tract infections at a university hospital. J Urol 150: 414-416.

13. Sefton AM (2000) The impact of resistance on the management of urinary tract infections. Int J Antimicrob Agents 16: 489-491.

14. Beyene G, Tsegaye W (2011) Bacterial uropathogens in urinary tract infection and antibiotic susceptibility pattern in jimma university specialized hospital, southwest ethiopia. Ethiopian $\mathrm{j}$ health sci 21 : 141-146.

15. Wilson ML, Gaido L (2004) Laboratory diagnosis of urinary tract infections in adult patients. Clin Infect Dis 38: 1150-1158.

16. Bonadio M, Meini M, Spetaleri P, Gilgi C (2001) Current microbiological and clinical aspects of urinary tract infections. Eur J Urol 40: 439-445.

17. Grude N, Tveten Y, Kristiansen BE (2001) Urinary tract infections in Norway: bacterial etiology and susceptibility, a retrospective study of clinical isolates. Clin Microbiol Infect 7: 543-547.

18. Farrell DJ, Morrissey I, De Rubeis D (2003) A UK multicentre study of the antimicrobial susceptibility of bacterial pathogens causing urinary tract infection. J Infect 46: 94-100.

19. Mathai D, Jones RN, Pfaller MA (2001) Epidemiology and frequency of resistance among pathogens causing urinary ntract infection in 1,510 hospitalized patients: A report from the SENTRY antimicrobial surveillance program (North America). Diag Microbiol Infect Dis 40: 129-136.

20. Farajnia S, Alikhani MY, Ghotaslou R, Naghili B, Nakhlband A (2009) Causative agents and antimicrobial susceptibilities of urinary tract infections in the northwest of Iran. Int J Infect Dis 13: $140-144$.

21. Adukauskiene D, Kinderyte A, Tarasevicius R (2006) Etiology, risk factors and outcome of urinary tract infection. Medicina (Kaunas) 42: 805-809.

22. Tessema B, Kassu A, Mulu A, Yismaw G (2007) Predominant isolates of urinary tract pathogens and their susceptibility patterns in gonder Univesity teaching hospital, Northwest Ethiopia. Ethio Med J 45: 61-67.

23. Ferry S, Burman LG, Holm SE (1998) Clinical and bacteriological effects of therapy of urinary tract infection in primary health care: Relation to in vitro sensitivity testing. Scand J Infect Dis 20: 535-544.

24. Henry D, Ellison W, Sullivan J, Mansfield DL, Magner DJ, et al. (1998) Treatment of community acquired acute uncomplicated urinary tract infection with sparfloxacin versus ofloxacin. The Sparfloxacin multi-center UUTI study group. Antimicrob Agents Chemother 42: 2262-2266.

25. Hryniewicz K, Szczypa K, Sulikowska A, Jankowski K, Betlejewska $\mathrm{K}$, et al. (2001) Antibiotic susceptibility of bacterial strains isolated from urinary tract infections in Poland. J Antimicrob Chemother 47: 773-780.

26. Cunha BA (2010) Urinary Tract Infection, Females. J eMedicine.

27. Dielubanza EJ, Schaeffer AJ (January 2011) Urinary tract infections in women". Med clin North Am 95: 27-41.

28. Foxman B (2003) Epidemiology of urinary tract infections: Incidence, morbidity, and economic costs. Dis Mon 49: 53-70.

29. Daoud Z, Afif C (2011) Escherichia coli isolated from urinary tract infections of Lebanese patients between 2000 and 2009: Epidemiology and profiles of resistance. Chemother Res Pract.

30. Raynor, MC, Carson CC (2011) Urinary infections in men". Med clin North Am 95: 43-54.

31. Mansour A, Manijeh M, Zohreh P (2009) Study of bacteria isolated from urinary tract infections and determination of their susceptibility to antibiotics. Jundishapur J Microbiol 118-23.

32. Abu Shaqra Q (2000) Occurrence and antibiotic sensitivity of Enterobacteriaceae isolated from a group of Jordanian patients with community acquired urinary tract infections. Cytobios 101: $15-21$.

33. Kumar MS, Lakshmi V, Rajagopalan R (2006) Occurrence of extended spectrum beta-lactamases among Enterobacteriaceae spp. isolated at a tertiary care institute. Indian J Med Microbiol 24: 208.

34. Strom BL (1987) Sexual activity, contraceptive use, and other risk factors for symptomatic and asymptomatic bacteriuria. A case control study. Ann Intern Med 107: 816-23.

35. Bi XC, Zhang B, Ye YK (2009) Pathogen incidence and antibiotic resistance patterns of catheter-associated urinary tract infection in children. J Chemother 21: 661-665.

36. Raka L, Mulliqi-Osmani G, Berisha L, Begolli L, Omeragiq S, et al. (2004) Etiology and susceptibility of urinary tract isolates in Kosova. Int j antimicrob agent 23: 2-5.

37. Russell LC, Freddy MC, Michael BS, Ralph AL (2007) The predictability of urinary pathogens based on the urinalysis nitrite test in hospitalized patients. Hospital Pharm J 42: 52-56.

38. Obiogbolu $\mathrm{CH}$, Okonko IO, Anyamere CO, Adedeji AO, Akanbi $A O$, et al. (2009) Incidence of urinary tract infections (UTIs) among pregnant women in Akwa metropolis, Southeastern Nigeria. Sci Res Essays 4: 820-824.

39. Garofalo CK, Hooton TM, Martin SM (2007) Escerichia coli from urine of female pateints with urinary tract infections is competent for intracellular bacterial community formation. Infect Immun 75: 52-60. 
40. Astal ZY, Sharif FA (2002) Relationship between demographic characteristics and community-acquired urinary tract infection. EMHJ 8: 164-171.

41. Mclsaac WJ, Mazzulli T, Moineddin R, Raboud J, Ross S (2004) Uropathogen antibiotic resistance in adult women presenting to family physicians with acute uncomplicated cystitis. Can J Infect Dis Med Microbiol 15: 266-270.

42. Gupta K, Hooton TM, Stamm WE (2001) Increasing antimicrobial resistance and the management of uncomplicated community acquired urinary tract infections. Ann Intern Med 135: 41-50

43. Five Things Physicians and Patients Should Question (2015) Choosing wisely: An initiative of the ABIM Foundation. Am Urogynecol Soci.

44. Sonth SB, Solabannavar SS, Hadapad D, Gokale S (2015) Study of bacteriological profile of urinary tract infections in a tertiary care teaching hospital. Int J Curr Microbiol App Sci 4: 928-993.

45. Clinical and Laboratory Standards Institute (2010) Performance standards for antimicrobial susceptibility testing; 20th informational supplement.CLSI document M100-S20. Clinical and Laboratory Standards Institute, Wayne, PA.

46. Clinical and Laboratory Standards Institute (2014) Performance standards for antimicrobial susceptibility testing; 21st informational supplement. CLSI document M100-S24. Clinical and Laboratory Standards Institute, Wayne, PA.

47. Khan IU, Mirza IA, Ikram A, Afzal A, Ali S, et al. (2014) Antimicrobial susceptibility pattern of bacteria isolated from patients with urinary tract infection. J Coll Physicians Surg Pak 24: 840-844.

48. Manikandan C, Amsath A (2013) Antibiotic susceptibility pattern of Klebsiella pneumoniae isolated from urine samples. Int J Curr Microbiol App Sci 2: 330-337.

49. Koshesh M, Mansouri S, Hashemizadeh Z, Kalantar-Neyestanaki $D$ (2016) Identification of extended-spectrum $\beta$-lactamase genes and ampc- $\beta$-lactamase in clinical isolates of Escherichia coli recovered from patients with urinary tract infections in Kerman, Iran. Arch Pediatr Infec Dis. 